\title{
Quantification of Formate and Oxygen Coverages on Cu Under Industrial Methanol Synthesis Conditions
}

Nielsen, Niels D.; Jensen, Anker D.; Christensen, Jakob M.

Published in:

Catalysis Letters

Link to article, DOI:

10.1007/s10562-020-03162-7

Publication date:

2020

Document Version

Peer reviewed version

Link back to DTU Orbit

Citation (APA):

Nielsen, N. D., Jensen, A. D., \& Christensen, J. M. (2020). Quantification of Formate and Oxygen Coverages on $\mathrm{Cu}$ Under Industrial Methanol Synthesis Conditions. Catalysis Letters, 150(9), 2447-2456.

https://doi.org/10.1007/s10562-020-03162-7

\section{General rights}

Copyright and moral rights for the publications made accessible in the public portal are retained by the authors and/or other copyright owners and it is a condition of accessing publications that users recognise and abide by the legal requirements associated with these rights.

- Users may download and print one copy of any publication from the public portal for the purpose of private study or research.

- You may not further distribute the material or use it for any profit-making activity or commercial gain

- You may freely distribute the URL identifying the publication in the public portal 


\title{
Quantification of formate and oxygen coverages on $\mathrm{Cu}$ under industrial methanol synthesis conditions
}

Niels D. Nielsen, Anker D. Jensen and Jakob M. Christensen*

Department of Chemical and Biochemical Engineering, Technical University of Denmark,

Søltofts Plads B229, 2800 Kgs. Lyngby (Denmark).

*Correspondence to: jmc @kt.dtu.dk

\begin{abstract}
:
A method for quantifying the surface coverage of adsorbate species for reactions at high pressure and high temperature is presented. Methanol was synthesized from $\mathrm{CO}_{2} / \mathrm{CO} / \mathrm{H}_{2}(3 / 29 / 68)$ at $523 \mathrm{~K}$ and 50 bar on Raney $\mathrm{Cu}$, which yielded a turnover frequency (TOF) per $\mathrm{Cu}$ surface atom of $(6.22 \pm 1.04) \cdot 10^{-3} \mathrm{~s}^{-1}$. Rapid quenching by submerging the catalytic reactor in ice water during operation allowed the formate surface coverage on $\mathrm{Cu}\left(\theta_{\mathrm{Cu}-\mathrm{HCOO}}\right)$ at reaction conditions to be determined in a subsequent temperature programmed desorption experiment. This yielded $\theta_{\mathrm{Cu}-\mathrm{HCOO}}$ $=0.071 \pm 0.012 \mathrm{ML}$ and a corresponding TOF per adsorbed HCOO of $0.088 \pm 0.021 \mathrm{~s}^{-1} . \mathrm{CO}_{2}$ was essentially observed to be the exclusive source of methanol formation over Raney $\mathrm{Cu}$, as the $\mathrm{CO}$ in the syngas could be replaced by $\mathrm{N}_{2}$ without impact on the methanol formation rate. Based on this observation and the considerable support in the literature for a $\mathrm{CO}_{2}$-pathway via surface formate on $\mathrm{Cu}$ the TOF per surface formate species should represent the true rate of the catalytic cycle in $\mathrm{Cu}$-catalyzed methanol synthesis. Temperature programmed hydrogenation of Raney $\mathrm{Cu}$ and unsupported $\mathrm{Cu}$ after quenching during high-pressure operation did not indicate a presence of oxygen species $(\mathrm{O}$ or $\mathrm{OH})$ on the working $\mathrm{Cu}$ surface.
\end{abstract}

\section{Introduction}

The surface coverage of adsorbate species under reaction conditions is an important parameter for catalytic reactions. This also applies for the $\mathrm{Cu}$-catalyzed hydrogenation of $\mathrm{CO}_{2}$ to methanol. Methanol synthesis from $\mathrm{CO}_{2}$ is a major industrial process from coal or natural gas derived syngas $\left(\mathrm{CO} / \mathrm{CO}_{2} / \mathrm{H}_{2}\right)$ and could have applications for storage of renewable energy in the form of methanol [1]. In methanol synthesis formate (HCOO) is an important adsorbate to quantify on the metallic $\mathrm{Cu}$ surface. Formate is an important reaction intermediate as indicated by the correspondence between disappearance of formate on $\mathrm{Cu}$ and the appearance of methoxide/methanol [2] and by the similar response of methanol production and formate IR bands to variations in the $\mathrm{CO}_{2}$ pressure [3, 4]. In situ infrared spectroscopy [3] and sum frequency generation [5] studies on supported and unsupported $\mathrm{Cu}$ have unambiguously identified $\mathrm{HCOO}$ on the copper surface under methanol synthesis conditions, but no quantification of $\theta_{\mathrm{Cu}-\mathrm{HCOO}}$ was provided. Gravimetric analyses [6] show that the industrial $\mathrm{Cu} / \mathrm{ZnO} / \mathrm{Al}_{2} \mathrm{O}_{3}$ catalyst is highly covered by surface adsorbates in a syngas atmosphere at high pressure, but this technique cannot distinguish between adsorbates on the metal and oxide components of the catalyst. Experimental approaches to quantification of $\theta_{\mathrm{Cu}-\mathrm{HCOO}}$ include X-ray Photoelectron Spectroscopy (XPS) post methanol synthesis (523 K, 18 bar) on $\mathrm{Cu}$ single crystals yielding $\theta_{\mathrm{Cu}-\mathrm{HCOO}} \cong 0.005-0.024 \mathrm{ML}$ [7] and temperature programmed desorption (TPD) after methanol synthesis $(1 \mathrm{~atm}, 438 \mathrm{~K})$ on $\mathrm{Cu} / \mathrm{ZnO}$ catalysts resulting in $\theta_{\mathrm{Cu}-\mathrm{HCOO}}=0.083$ [2]. However, these studies provide no details regarding the post reaction cooling procedure, which ideally should be infinitely fast to quench the working state of the catalyst. Micro-kinetic models 
[8-13] based on Cu surface science data or DFT calculations report formate coverages in the entire range from sub-percentage levels to full coverage under industrial methanol synthesis conditions and thus offer no unified estimate of $\theta_{\mathrm{Cu}-\mathrm{HCOO}}$. Quantitative estimates of the formate coverage on $\mathrm{Cu}$ at industrially relevant conditions $(\mathrm{T}=523 \mathrm{~K}, \mathrm{P}=50$ bar [14]) are therefore necessary to improve the fundamental understanding of the $\mathrm{Cu}$-catalyzed methanol synthesis and guide kinetic modelling studies.

This study presents a quantitative method for determination of $\theta_{\mathrm{Cu}-\mathrm{HCOO}}$ on $\mathrm{Cu}$ during methanol synthesis by integrating the desorbed amount of $\mathrm{CO}_{2}$ in a TPD experiment after rapid quenching of the working catalyst by submerging the reactor in a cooling medium. Coverages are reported as the number of adsorbates relative to the total number of $\mathrm{Cu}$ surface atoms. For adsorbates such as HCOO that tend to adopt a bidentate configuration with bonding to two copper atoms full coverage should thus correspond to 0.5 ML. Raney $\mathrm{Cu}$ was used to approximate the intrinsic properties of $\mathrm{Cu}$ because it was observed to have superior thermal stability compared to unsupported $\mathrm{Cu}$, and studies on Raney $\mathrm{Cu}$ thus improve the reliability of the analyses. Comparisons of the TOF for $\mathrm{CO}_{2}$ hydrogenation for Raney $\mathrm{Cu}$ to measurements on unsupported $\mathrm{Cu}$ and to single crystal values from the literature are used to support that Raney $\mathrm{Cu}$ is a reasonable model for the intrinsic properties of $\mathrm{Cu}$.

\section{Experimental}

\subsection{Catalysts}

Raney $\mathrm{Cu}$ from Strem Chemicals (The producer reports: $98.9 \mathrm{wt} \% \mathrm{Cu}, 0.81 \mathrm{wt} \% \mathrm{Al}, 0.1 \mathrm{wt} \% \mathrm{Fe}$, $0.05 \mathrm{wt} \% \mathrm{Ni}$ ) was received as an aqueous slurry, from which small portions were pre-dried in air at room temperature in a fume hood before loading it into the reactor. This method proved more convenient and no difference in catalytic activity was observed between loading in a wet or dried state. Unsupported $\mathrm{Cu}$ was obtained from pure $\mathrm{CuO}$. The $\mathrm{CuO}$ used to produce unsupported $\mathrm{Cu}$ for activity tests was prepared by precipitation from the nitrate and calcination to $\mathrm{CuO}$ in flowing air as described in detail elsewhere [15]. The $\mathrm{CuO}$ used to generate unsupported $\mathrm{Cu}$ for the TPH experiment identifying adsorbed oxygen on the working copper surface was $\mathrm{CuO}$ nanopowder $(<50 \mathrm{~nm})$ from Sigma Aldrich.

\subsection{Experimental setup}

Methanol synthesis experiments and subsequent TPD or temperature programmed hydrogenation (TPH) experiments to quantify adsorbate coverages were conducted in a high pressure flow reactor setup described in more detail elsewhere [15]. In brief, the catalyst was placed in a U-tube reactor (SGE Analytical Science borosilicate glass lined steel). The U-tube reactor was placed within an Entech tubular oven that can be opened rapidly to access the reactor. Thereby the U-tube reactor containing the catalyst can be cooled rapidly by raising a liquid (ice water, boiling water or liquid $\mathrm{N}_{2}$ ) filled dewar to submerge the U-tube in the cooling liquid. The effluent from the reactor during catalytic reaction and temperature programmed experiments was analyzed using a Thermo Fisher Trace 1300 GC and a Hiden HPR-20 EGA mass spectrometer. 


\subsection{Activation of catalyst by $\mathrm{H}_{2}$ reduction}

Raney $\mathrm{Cu}$ is partly oxidized during storage or during the pre-drying of the sample. Thus before any use, Raney $\mathrm{Cu}$ was reduced in situ in $5 \% \mathrm{H}_{2} / \mathrm{N}_{2}$ by ramping with $1 \mathrm{~K} / \mathrm{min}$ to first $448 \mathrm{~K}$ and secondly to $523 \mathrm{~K}$ with a 2 hour dwell time at both temperatures. A similar activation procedure was initially employed for unsupported $\mathrm{Cu}$, but water evolution terminated at the $448 \mathrm{~K}$ step indicating complete reduction already at $448 \mathrm{~K}$. Because unsupported $\mathrm{Cu}$ was less thermally stable and fully reduced already at $448 \mathrm{~K}$ all results reported for unsupported $\mathrm{Cu}$ are obtained with prereduction at $448 \mathrm{~K}(1 \mathrm{~K} / \mathrm{min}, 2 \mathrm{~h}$ holding time $)$.

\subsection{Surface area measurement}

The specific $\mathrm{Cu}$ surface area was evaluated based on the $\mathrm{N}_{2} \mathrm{O}$ Reactive Frontal Chromatography (RFC) method [16]. The pre-reduced/activated catalyst was exposed to $19 \mathrm{Nml} / \mathrm{min}$ of $1 \% \mathrm{~N}_{2} \mathrm{O} / \mathrm{He}$ at $333 \mathrm{~K}$ and ambient pressure. The $\mathrm{N}_{2} \mathrm{O}$ consumption was converted into a $\mathrm{Cu}$ surface area assuming a $\mathrm{Cu}: \mathrm{O}$ stoichiometry of $2: 1[17]$ and an average $\mathrm{Cu}$ surface atom density of $1.47 \cdot 10^{19}$ atoms $/\left(\mathrm{m}^{2} \mathrm{Cu}\right)$ [18] based on the arithmetic mean of the low index $\mathrm{Cu}$ facets $(\mathrm{Cu}(111), \mathrm{Cu}(100)$ and $\mathrm{Cu}(110))$. $\mathrm{N}_{2} \mathrm{O}-\mathrm{RFC}$ was conducted both in a Quantachrome $\mathrm{IQ}_{2}$ setup and in the high pressure setup also applied for the quenching and methanol activity experiments.

The Raney $\mathrm{Cu}$ sample contained residual $\mathrm{Al}$ in the form of $\mathrm{Al}_{2} \mathrm{O}_{3}$. Because of the low surface free energies of oxides compared to metals [19] the oxide components in Raney $\mathrm{Cu}$ may represent a larger concentration on the surface. The extent of the $\mathrm{Al}_{2} \mathrm{O}_{3}$ covered surface was determined from the difference between a BET measurement of the total surface area and an $\mathrm{N}_{2} \mathrm{O}-\mathrm{RFC}$ measurement of the metallic $\mathrm{Cu}$ surface area. A Quantachrome NOVAtouch Gas sorption analyzer was applied to perform the BET analysis. Pre-dried Raney $\mathrm{Cu}$ was reduced ex-situ (see section 3.2) with fixed temperature for 4 hours (due to use of a larger amount of sample) at $448 \mathrm{~K}$ and 2 hours at $523 \mathrm{~K}$ before $\mathrm{He}$ flush and cooling to room temperature. The ex-situ activated Raney $\mathrm{Cu}$ was then loaded into the NOVAtouch analyzer and vacuum degassed with $10 \mathrm{~K} / \mathrm{min}$ heating to $423 \mathrm{~K}$ and holding for 16 hours. Degassed Raney $\mathrm{Cu}$ was weighed before performing a standard 6-point BET surface area measurement.

\subsection{Measurement of catalytic activity and activation energy}

After catalyst pre-reduction the reactor was pressurized to 50 bar in $\mathrm{He}(99.999 \%)$ and the catalyst was then subjected to the reaction gas, which was mixed from pure $\mathrm{H}_{2}(99.999 \%)$ and pre-mixed $9.00 \mathrm{~mol} \% \mathrm{CO}_{2}$ in $\mathrm{CO}$ or $9.00 \mathrm{~mol} \% \mathrm{CO}_{2}$ in $\mathrm{N}_{2}$ (all gasses from Air Liquide Denmark). The methanol concentration in the effluent was measured by gas chromatography, and the effluent flow was measured by a soap film flowmeter. For determining the activation energy pre-reduced Raney $\mathrm{Cu}$ was cooled to $423 \mathrm{~K}$ and pressurized in He before feeding with $280 \mathrm{Nml} / \mathrm{min}$ of $\mathrm{CO}_{2} / \mathrm{CO} / \mathrm{H}_{2}$ (3/29/68). The reaction temperature was raised in steps of $20 \mathrm{~K}$ from $423 \mathrm{~K}$ to $523 \mathrm{~K}$ each time with a fixed temperature for 1-2 hours to reach a stable methanol effluent concentration, which was quantified by online gas chromatography. 


\subsection{Procedure to estimate the surface coverage of formate on $\mathrm{Cu}$}

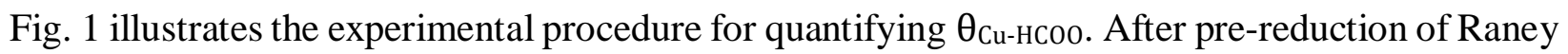
$\mathrm{Cu}$, the reactor was at $523 \mathrm{~K}$ pressurized in $\mathrm{He}$ to 50 bar before feeding $280 \mathrm{Nml} / \mathrm{min}$ of $\mathrm{CO}_{2} / \mathrm{CO} / \mathrm{H}_{2}=3 / 29 / 68$ at constant temperature and pressure. All measurements were conducted at differential conditions with a maximum of $0.10 \mathrm{~mol} \%$ methanol in the effluent gas stream. Once the methanol signal (evaluated by the MS using $\mathrm{m} / \mathrm{z}=31$ ) reached its peak level, the methanol production was quantified by a GC measurement, before the catalyst was rapidly cooled in the reaction gas by different cooling methods described below. At room temperature or below, the syngas pressure was released, and the reactor was thoroughly purged with He before conducting a TPD in flowing He with a $2 \mathrm{~K} / \mathrm{min}$ heating ramp.

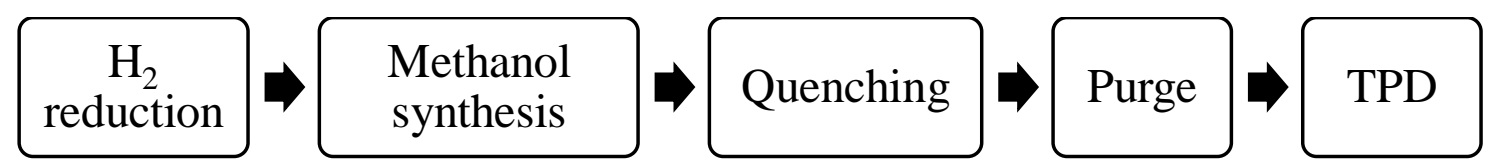

Fig. 1 Block diagram of the protocol for quantifying the surface adsorbate coverage at reaction conditions on Raney $\mathrm{Cu}$.

Fig. 2 shows the cooling profile measured by two thermocouples (TCs) - one placed inside the reactor tube at the top of the catalyst bed (red) and one on the external surface of the reactor tube at the bottom of the catalyst bed (blue). The cooling was set to start at $t=0$ in Fig. 2 by swiftly opening the oven and moving a dewar filled with the cooling liquid (ice water was used in Fig. 2) vertically upwards to cool the U-shaped reactor (see Fig. 2), and after a few seconds both TCs were at (or below) room temperature. The cooling profile experienced by the catalyst bed is an average of the temperature profiles measured by the two TCs, and this average is plotted as $T_{\text {ave }}$ in Fig. 2. In the case of cooling with boiling water, the dewar was removed after cooling to $383 \mathrm{~K}$ and further cooling was due to ambient air circulation around the U-shaped reactor. Cooling by static air occurred by opening the oven and allowing the reactor to cool by the ambient room temperature air. Two additional repetition experiments confirmed the reproducibility of quenching profiles with ice water (see supplementary information Fig. S1). After cooling to room temperature or below, the pressure was released, and the syngas was thoroughly flushed out with He before removing the dewar with the cooling liquid (except for boiling water where the dewar was removed at $383 \mathrm{~K}$ ) under continuous $\mathrm{He}$ flush and allowing the reactor to heat naturally to room temperature, if the temperature during $\mathrm{He}$ purging was below room temperature. Starting from room temperature, a TPD was carried out with $2 \mathrm{~K} / \mathrm{min}$ heating to $673 \mathrm{~K}$ in a He flow. The He flow was calibrated for each experiment using a soap film bubble flow meter and was within the interval from 42 to $45 \mathrm{Nml} / \mathrm{min}$. A Hiden EGA mass spectrometer continuously measured desorbing $\mathrm{CO}_{2}$ $(\mathrm{m} / \mathrm{z}=44), \mathrm{CO}(\mathrm{m} / \mathrm{z}=28), \mathrm{H}_{2} \mathrm{O}(\mathrm{m} / \mathrm{z}=18)$ and $\mathrm{H}_{2}(\mathrm{~m} / \mathrm{z}=2)$. 


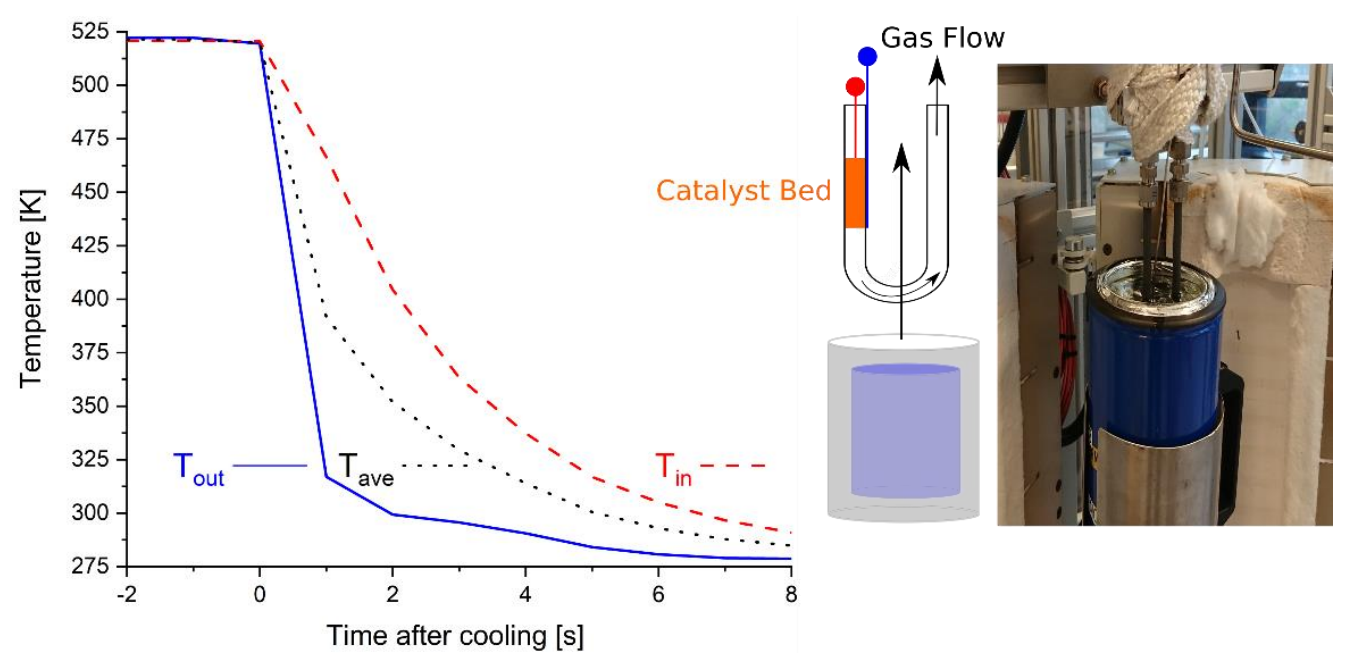

Fig. 2 Left: Cooling of the catalyst in the reaction mixture started at $t=0$, while two thermocouples (TCs) positioned inside at the top (red, dashed) of the catalyst bed (orange) and outside at the bottom of the catalyst bed (blue, solid) monitored the cooling process. Right: Schematic view of cooling process by raising the filled dewar to submerge and cool the U-tube including positions of the thermocouples (red and blue). Far right: Image of the U-tube submerged in ice water.

The $\mathrm{CO}_{2}$ MS signal was calibrated using a certified $500 \mathrm{ppm} \mathrm{CO}_{2}$ in $\mathrm{He}$ gas mixture from Air Liquide Denmark. This allowed determination of $\theta_{\mathrm{Cu}-\mathrm{HCOO}}$ from integration of the calibrated $\mathrm{CO}_{2}$ signal. Desorbed $\mathrm{H}_{2}$ could in principle also be used to quantify $\theta_{\mathrm{Cu}-\mathrm{HCOO}}$, since $\mathrm{HCOO}$ on $\mathrm{Cu}$ decomposes to $\mathrm{CO}_{2}$ and $\mathrm{H}_{2}$, but the hydrogen desorption was observed to be very complex with multiple peaks - most likely from decomposition of species on both the metal and $\mathrm{Al}_{2} \mathrm{O}_{3}$ parts of the surface yielding $\mathrm{H}_{2}$. It was therefore concluded that it was too complex to quantify $\theta_{\mathrm{Cu}-\mathrm{HCOO}}$ based on desorbed $\mathrm{H}_{2}$.

\subsection{Evaluation of the coverage of adsorbed oxygen by temperature programmed hydrogenation}

Two TPH experiments were designed to evaluate the coverage of adsorbed oxygen species (O or $\mathrm{OH}$ ) on the $\mathrm{Cu}$ surface under reaction conditions. Both TPHs were performed in $60 \mathrm{Nm} / \mathrm{min}$ flow of $5 \% \mathrm{H}_{2} / \mathrm{N}_{2}$ with $2 \mathrm{~K} / \mathrm{min}$ heating ramp from $300 \mathrm{~K}$ to $673 \mathrm{~K}$. In one experiment pre-reduced $\mathrm{Cu}$ was oxidized by $1 \mathrm{~mol} \% \mathrm{~N}_{2} \mathrm{O}$ in $\mathrm{He}$ at $333 \mathrm{~K}$, which yields half a monolayer of oxygen on $\mathrm{Cu}$ as verified by studies $[16,17]$ benchmarking $\mathrm{N}_{2} \mathrm{O}-\mathrm{RFC}$ against BET surface area measurements. Next, the half monolayer of oxygen was hydrogenated in a TPH and formed $\mathrm{H}_{2} \mathrm{O}$ was quantified to calibrate the $\mathrm{H}_{2} \mathrm{O}(\mathrm{m} / \mathrm{z}=18) \mathrm{MS}$ signal by equating the integral $\mathrm{H}_{2} \mathrm{O}$ signal to $0.5 \mathrm{ML}$ of $\mathrm{O}$. In a second experiment the working catalyst was quenched using ice water (see section 2.5) and then subjected to a TPH instead of TPD. The oxygen coverage on the working catalyst was estimated from integration of the $\mathrm{H}_{2} \mathrm{O}$ MS signal acquired during TPH of the quenched catalyst. A blank TPH experiment without catalyst (but similar to the procedure for the second experiment) showed no gas desorption thus verifying that products formed in the two TPH experiments were associated with the catalyst. 


\subsection{X-ray photo-electron spectroscopy on Raney $\mathrm{Cu}$ and unsupported $\mathrm{CuO}$}

XPS analyses were performed on Raney $\mathrm{Cu}$ and unsupported $\mathrm{CuO}$ to qualitatively assess the surface composition of Raney $\mathrm{Cu}$. The XPS source was a monochromatic and micro-focused Al K-Alpha source $(1486.6 \mathrm{eV})$ with a $180^{\circ}$ double focusing hemispherical analyzer and a 128 channel detector from Thermo Scientific with an optimal base pressure of $6 \cdot 10^{-9}$ mbar. XPS experiments were performed with a chamber pressure of $4 \cdot 10^{-8}$ mbar and analysed using the Avantage software. Survey spectra were acquired for fresh unsupported $\mathrm{CuO}$, predried Raney $\mathrm{Cu}$ and predried and then reduced Raney $\mathrm{Cu}$. Survey spectra were recorded for all three samples and extra spectra were recorded to detect $\mathrm{Al}$ in Raney $\mathrm{Cu}$.

\section{Results \& Discussion}

\subsection{Surface composition of Raney $\mathrm{Cu}$}

In agreement with previous XPS studies [20] on Raney $\mathrm{Cu}$ ex situ XPS measurements (see supplementary material Fig. S14- Fig. S17) on the pre-reduced Raney Cu sample showed that there were two peaks in the 70-80 eV range, namely a Cu3p peak at ca. $78 \mathrm{eV}$ and an $\mathrm{Al} 2 \mathrm{p}$ peak at 75 $\mathrm{eV}$ (see Fig. S16). The binding energy of the Al2p peak suggests that the $\mathrm{Al}$ was in an oxidized $\mathrm{Al}_{2} \mathrm{O}_{3}$ form [20-23]. This shows that the surface of Raney $\mathrm{Cu}$ is partly covered by $\mathrm{Al}_{2} \mathrm{O}_{3} \cdot \mathrm{N}_{2} \mathrm{O}-$ $\mathrm{RFC}$ yielded a $\mathrm{Cu}$ metal area of $5.18 \mathrm{~m}^{2} / \mathrm{g}$ for Raney $\mathrm{Cu}$, whereas the BET area of the pre-reduced catalyst, which includes both the metallic $\mathrm{Cu}$ surface and the $\mathrm{Al}_{2} \mathrm{O}_{3}$ covered surface, yielded 13.94 $\mathrm{m}^{2} / \mathrm{g}$. Consequently, the $\mathrm{Al}_{2} \mathrm{O}_{3}$ covered the major part of the surface (by difference between BET and $\mathrm{N}_{2} \mathrm{O}-\mathrm{RFC}$ around $8.8 \mathrm{~m}^{2} / \mathrm{g}$ ) despite $\mathrm{Al}$ constituting less than $1 \mathrm{wt} \%$ of Raney $\mathrm{Cu}$.

\subsection{Benchmarking against the intrinsic properties of $\mathrm{Cu}$}

The present work seeks to evaluate the intrinsic properties of $\mathrm{Cu}$ at a realistic methanol synthesis temperature of $523 \mathrm{~K}$, and Raney $\mathrm{Cu}$ was used because it has a reasonable thermal stability at these conditions. However, as discussed above the Raney $\mathrm{Cu}$ sample also had an extensive oxide surface and thus sites such as the $\mathrm{Cu}$ /oxide interface that are not present in pure $\mathrm{Cu}$. To evaluate, if Raney $\mathrm{Cu}$ is a reasonable approximation of the intrinsic properties of $\mathrm{Cu}$ concerning methanol synthesis, the rate of $\mathrm{CO}_{2}$ hydrogenation to methanol was compared to unsupported $\mathrm{Cu}\left(0.494 \mathrm{~m}^{2} \mathrm{Cu} / \mathrm{g}_{\text {cat }}\right)$. Both Raney $\mathrm{Cu}$ and unsupported $\mathrm{Cu}$ were tested at $498 \mathrm{~K}$ in $\mathrm{CO}_{2} / \mathrm{N}_{2} / \mathrm{H}_{2}=3 / 29 / 68$ at 50 bar of pressure and showed very similar TOFs of $3.65 \cdot 10^{-3} \mathrm{~s}^{-1}$ and $2.78 \cdot 10^{-3} \mathrm{~s}^{-1}$, respectively (Table 1). The evaluation was performed at $498 \mathrm{~K}$ rather than $523 \mathrm{~K}$, as measurements of unsupported $\mathrm{Cu}$ were unreliable at $523 \mathrm{~K}$, where it transited from powder to a massive pellet. Rapid activity loss for unsupported $\mathrm{Cu}$ at $523 \mathrm{~K}$ is also known in the literature [24]. Unsupported $\mathrm{Cu}$ is prone to sintering due to a low Hüttig temperature $(408 \mathrm{~K})$ above which surface mobility becomes significant [25], and copper particles are known to agglomerate above $473 \mathrm{~K}$ [26]. Given the propensity of unsupported $\mathrm{Cu}$ towards sintering the TOF agreement within ca. $25 \%$ between unsupported and Raney $\mathrm{Cu}$ is taken as evidence that Raney $\mathrm{Cu}$ is a good approximation of the 
intrinsic properties of $\mathrm{Cu}$. By assuming a linear hydrogen pressure dependence, as also employed by others [11], and utilizing reported activation energies under the assumption of an Arrheniustype temperature dependence, previously reported [27, 28] TOF-values for $\mathrm{CO}_{2}$ hydrogenation on $\mathrm{Cu}(111)$ and polycrystalline $\mathrm{Cu}$ were extrapolated to the present conditions $\left(498 \mathrm{~K}, \mathrm{p}_{\mathrm{H}_{2}}=34 \mathrm{bar}\right)$.

Table 1 compares these extrapolated TOF-values [27, 28] to the ones for Raney $\mathrm{Cu}$ and unsupported $\mathrm{Cu}$ obtained in this study, and the results generally show a good agreement. Based on the correspondence in TOF between Raney $\mathrm{Cu}$ and both unsupported $\mathrm{Cu}$ and previous single crystal studies it is concluded that Raney $\mathrm{Cu}$ is a reasonably good approximation to the intrinsic properties of copper.

Table 1 TOF values for Raney $\mathrm{Cu}$ and unsupported $\mathrm{Cu}$ at $498 \mathrm{~K}, 50$ bar, $\mathrm{CO}_{2} / \mathrm{N}_{2} / \mathrm{H}_{2}=3 / 29 / 68$ and TOF-values from single crystal studies extrapolated to the conditions of this study ( $\mathrm{T}=498$ $\mathrm{K}, \mathrm{p}_{2}=34$ bar) using their reported activation energies.

\begin{tabular}{|c|c|c|c|c|c|c|}
\hline Catalyst & $\begin{array}{c}\mathbf{T} \\
{[\mathbf{K}]}\end{array}$ & $\begin{array}{c}\mathbf{p}_{\mathbf{H}_{2}} \\
{[\mathbf{b a r}]}\end{array}$ & $\begin{array}{c}\mathbf{E}_{\text {act }} \text { reported } \\
{[\mathbf{k J} / \mathbf{m o l}]}\end{array}$ & $\begin{array}{c}\text { TOF } \\
\text { reported } \\
{\left[\mathbf{s}^{-1}\right]}\end{array}$ & $\begin{array}{c}\text { TOF } \\
\text { extrapolated } \\
{\left[\mathbf{s}^{-1}\right]}\end{array}$ & Reference \\
\hline $\mathrm{Cu}(111)$ & 523 & 13.5 & 73.6 & $2.06 \cdot 10^{-3}$ & $2.07 \cdot 10^{-3}$ & {$[27]$} \\
\hline Polycrystal. $\mathrm{Cu}$ & 510 & 4.67 & 77 & $1.2 \cdot 10^{-3}$ & $5.7 \cdot 10^{-3}$ & {$[28]$} \\
\hline Unsupported $\mathrm{Cu}$ & 498 & 34 & & $2.78 \cdot 10^{-3}$ & $2.78 \cdot 10^{-3}$ & This study \\
\hline Raney $\mathrm{Cu}$ & 498 & 34 & 55.3 & $3.65 \cdot 10^{-3}$ & $3.65 \cdot 10^{-3}$ & This study \\
\hline
\end{tabular}

The methanol synthesis rate in $\mathrm{CO} / \mathrm{CO}_{2} / \mathrm{H}_{2}$ was measured at 50 bar and temperatures ranging from $423 \mathrm{~K}$ to $523 \mathrm{~K}$ to determine the activation energy for the methanol synthesis on Raney Cu. Fig. 3 shows an Arrhenius plot determined from these measurements, which yields an apparent activation energy of $55.3 \mathrm{~kJ} / \mathrm{mol}$. Previous measurements [15] in the same setup on unsupported $\mathrm{Cu}$ at $50 \mathrm{bar}$ and a $\mathrm{CO}_{2} / \mathrm{H}_{2}$ feed suggest an activation energy of $60 \mathrm{~kJ} / \mathrm{mol}$ for unsupported $\mathrm{Cu}$, which within the uncertainty also indicates a reasonable agreement between Raney $\mathrm{Cu}$ and unsupported $\mathrm{Cu}$ in terms of the activation energy. 


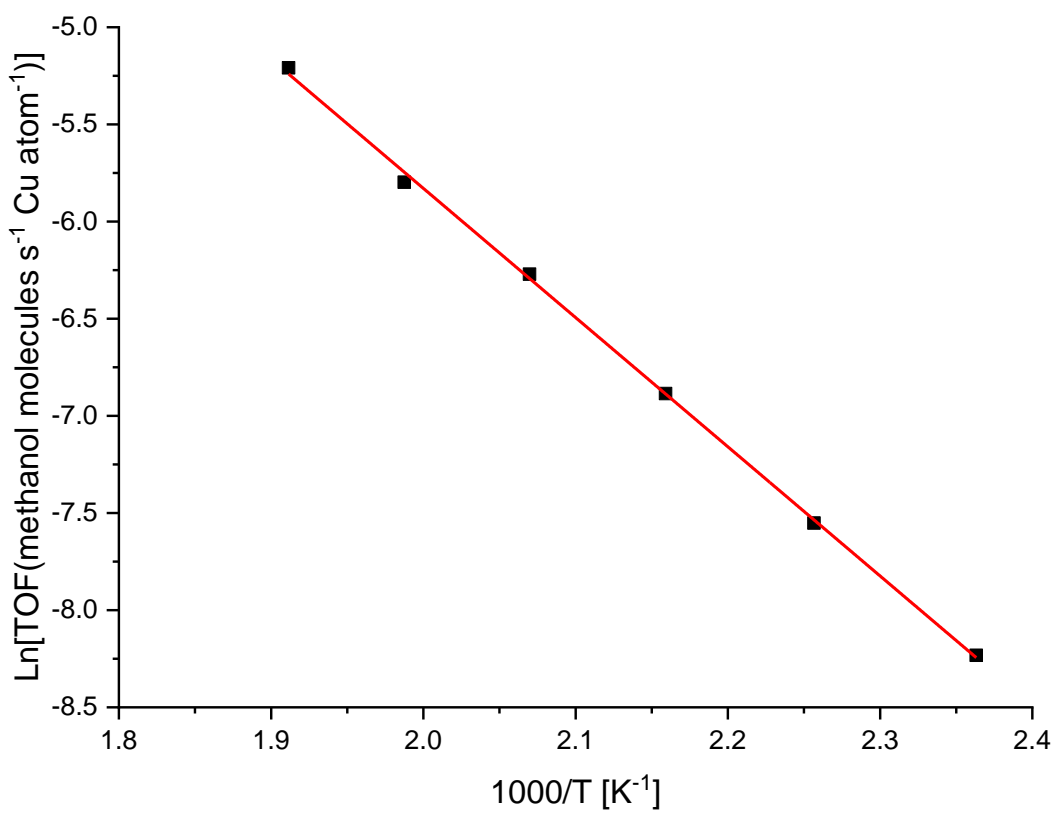

Fig. 3 Arrhenius plot for methanol synthesis over Raney $\mathrm{Cu}$ exposed to reaction conditions (50 bar, $\mathrm{CO}_{2} / \mathrm{CO} / \mathrm{H}_{2}=3 / 29 / 68, \mathrm{GHSV}=6.7 \cdot 10^{4} \mathrm{Nml} / \mathrm{g}_{\text {cat }} / \mathrm{h}$ ).

\subsection{Formate quantification by a TPD method}

Raney $\mathrm{Cu}$ was allowed to reach steady state in $\mathrm{CO}_{2} / \mathrm{CO} / \mathrm{H}_{2}$ at 50 bar and $523 \mathrm{~K}$. At that point the activity was measured by gas chromatography, and the catalyst was rapidly quenched by submerging the U-tube reactor in ice water. The ice water cooling yielded reproducible and rapid cooling profiles (see Fig. S1). The quenched sample was then subjected to a TPD, and Fig. 4 shows the evolution of $\mathrm{CO}, \mathrm{CO}_{2}, \mathrm{H}_{2}$ and $\mathrm{H}_{2} \mathrm{O}$ during the TPD. The reproducibility of the obtained TPD profiles was verified by three repeated experiments (see also Fig. S2 and Fig. S3). Fig. 5 shows the $\mathrm{CO}_{2}$ desorption deconvoluted into three Gaussian peaks termed $\alpha, \beta$, and $\gamma$. The main $\mathrm{CO}_{2}$ desorption (the $\beta$-peak) occurred at $410 \mathrm{~K}$. In a Redhead analysis [29, 30] with the commonly applied pre-factor of $10^{13} \mathrm{~s}^{-1}$ this temperature corresponds to an activation energy for desorption of $122 \mathrm{~kJ} / \mathrm{mol}$, which is consistent with formate desorption from $\mathrm{Cu}$ [31-34]. Fujita et al. [2] also observed that the $\mathrm{CO}_{2}$ TPD peak corresponding to the $\beta$-peak in Fig. 4 scaled with the $\mathrm{Cu}$ surface area for a range of formate covered $\mathrm{Cu} / \mathrm{ZnO}$ samples. This further supports that the $\mathrm{CO}_{2} \beta$-peak arises from a species on the $\mathrm{Cu}$ surface. Although the hydrogen desorption was too diffuse to be used in quantification, the $\mathrm{CO}_{2} \beta$-peak also coincided with a shoulder in the $\mathrm{H}_{2}$ desorption, which is consistent with formate on $\mathrm{Cu}$ yielding desorption of both $\mathrm{CO}_{2}$ and $\mathrm{H}_{2}$. On this basis the $\mathrm{CO}_{2} \beta$ peak was unambiguously assigned to formate on $\mathrm{Cu}$. The $\beta$-peak was therefore used to determine $\theta_{\mathrm{Cu}-\mathrm{HCOO}}$, and the orange area in Fig. 5 marks the area integrated to calculate the formate coverage.

The main $\mathrm{CO}$ desorption peak at $464 \mathrm{~K}$ was assigned to methoxide on the $\mathrm{Al}_{2} \mathrm{O}_{3}$ part of the surface. The main argument for this assignment is that Tamm et al. [35] observed concurrent desorption of $\mathrm{CO}$ and $\mathrm{H}_{2}$ and to a lesser extent $\mathrm{CO}_{2}$ at a similar temperature during TPD after methanol adsorption on $\gamma-\mathrm{Al}_{2} \mathrm{O}_{3}$. The $\mathrm{CO}_{2} \gamma$-peak coincided with the $\mathrm{CO}$ desorption at $464 \mathrm{~K}$ and 
was therefore most likely also related to desorption from the oxide surface similar to the one also observed by Tamm et al. [35].

Desorption above $550 \mathrm{~K}$ must originate from highly stable adsorbed species most likely on the oxide and therefore not likely to influence the methanol synthesis reaction at $523 \mathrm{~K}$. It was reported that formate on $\mathrm{Al}_{2} \mathrm{O}_{3}$ may desorb as $\mathrm{CO}$ and $\mathrm{H}_{2} \mathrm{O}$ [36] at higher temperatures, and $\mathrm{Cu}$ might also facilitate water-gas shift $[37,38]$ of these species to $\mathrm{CO}_{2}$ and $\mathrm{H}_{2}$. The higher temperature desorption was therefore assigned to the oxide surface. As discussed in section 3.1 the oxide surface presents a major fraction of the total surface area, which supports that species on the oxide contributes significantly to desorbed gas species during post reaction TPD.

The lower temperature desorption below approximately $383 \mathrm{~K}$ was attributed to chemisorbed $\mathrm{H}_{2} \mathrm{O}$ and reactants on the sample. This includes the small, low temperature $\alpha-\mathrm{CO}_{2}$ peak in Fig. 5. As the $\alpha$-peak is centered at ca. $370 \mathrm{~K}$, where $\mathrm{CO}_{2}$ chemisorbed on $\mathrm{Al}_{2} \mathrm{O}_{3}$ is reported [39] to desorb, the $\alpha$-peak is attributed to chemisorbed $\mathrm{CO}_{2}$ on the alumina part of the surface and not included in the formate quantification. However, given the small size of the $\alpha$-peak this does not change the conclusions markedly.

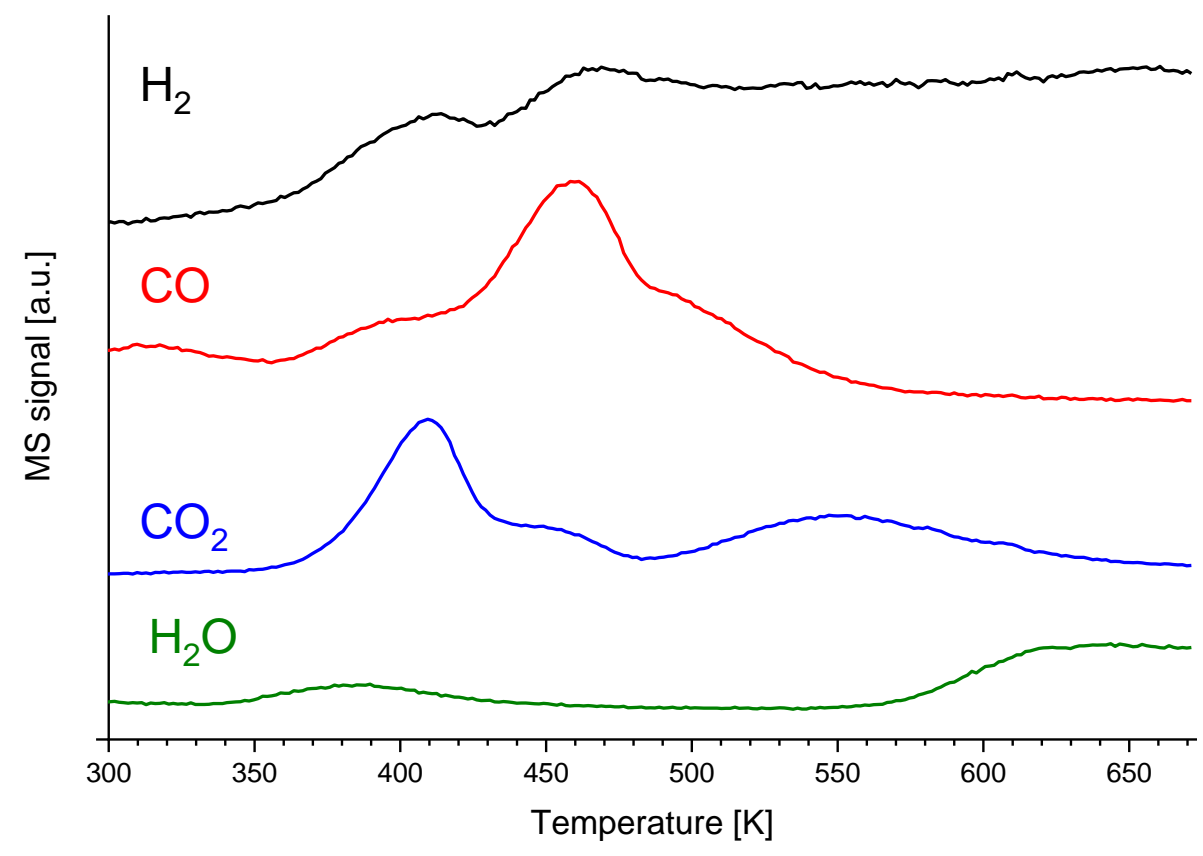

Fig. 4 Measured gas profiles during the TPD with $2 \mathrm{~K} / \mathrm{min}$ as heating ramp after methanol synthesis at $523 \mathrm{~K}, 50$ bar pressure in $\mathrm{CO}_{2} / \mathrm{CO} / \mathrm{H}_{2}=3 / 29 / 68$ and subsequent quenching. MS signals are vertically offset on the linear $\mathrm{y}$-axis for clarity. 


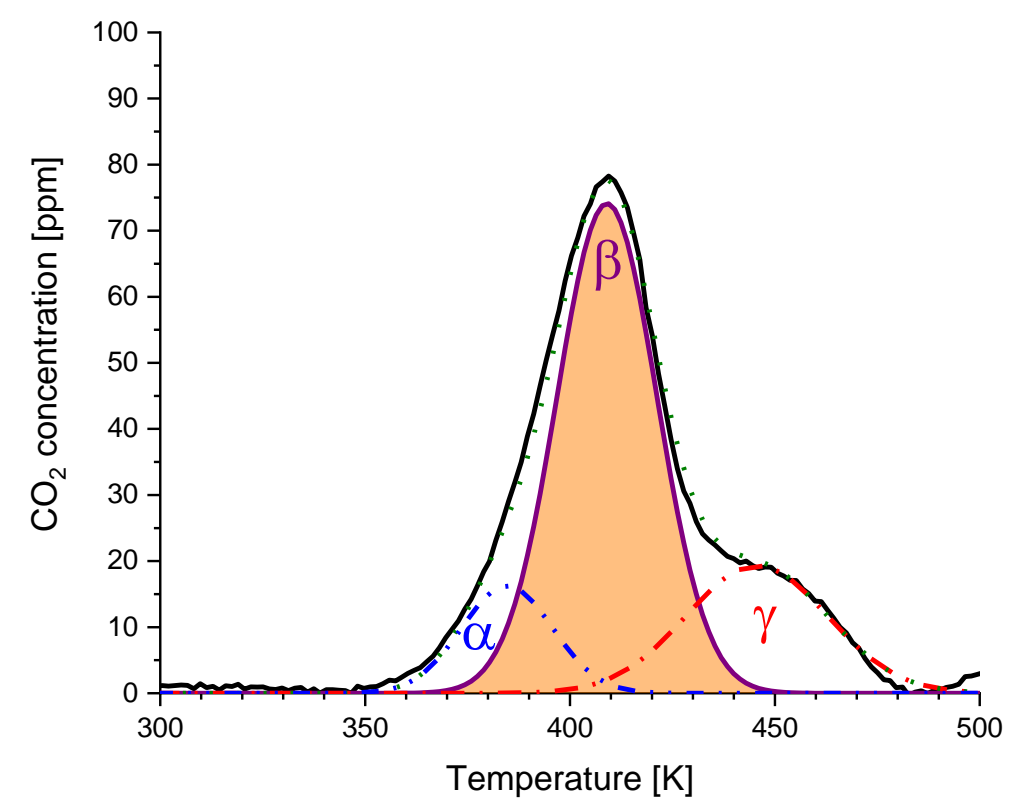

Fig. 5 Peak fitting to the measured black solid $\mathrm{CO}_{2}$ desorption line using three Gaussian peaks $(\alpha$, $\beta$, and $\gamma$ ), which sum up to dotted green profile. HCOO was quantified by the integrated area (orange) under the $\mathrm{CO}_{2} \beta$-peak. Heat ramp: $2 \mathrm{~K} / \mathrm{min}$. He flow: $42.5 \mathrm{Nml} / \mathrm{min}$.

\subsection{Evaluation of cooling methods}

We have previously [15] compared the rates of methanol formation from $\mathrm{CO}$ and $\mathrm{CO}_{2}$ on $\mathrm{Cu}$ with the same $\mathrm{Cu}$-based materials investigated here, and found that the rate from $\mathrm{CO}_{2}$ is approximately an order of magnitude faster than the rate from $\mathrm{CO}$. Additionally, an experiment was performed, where the $\mathrm{CO}$ in the syngas was exchanged with $\mathrm{N}_{2}$, and this had essentially no influence on the methanol formation rate (see Fig. S12). Consequently, there should be little uncertainty in attributing the entire methanol production to the pathway from $\mathrm{CO}_{2}$. There is considerable experimental data to support that the pathway from $\mathrm{CO}_{2}$ is via formate [2-4], and the formation and hydrogenation of formate can be expressed in a simplified manner by reactions R1 and R2 (with $\mathrm{HCOO}^{*}$ denoting adsorbed formate and $*$ denoting an active site) $[8,40]$ :

$\begin{array}{ll}\mathrm{CO}_{2}+\frac{1}{2} \mathrm{H}_{2}+{ }^{*} \rightleftharpoons \mathrm{HCOO}^{*} & \mathrm{R} 1 \\ \mathrm{HCOO}^{*} \stackrel{\text { Hyd. }}{\longrightarrow} \mathrm{CH}_{3} \mathrm{OH}+{ }^{*} & \mathrm{R} 2\end{array}$

To provide the true working coverage of the catalyst the quenching must therefore be rapid enough to avoid that neither R1 nor R2 change the coverage during cooling. To evaluate this the quenching rate was varied using different cooling media, and the measured formate coverages was compared after cooling with ice water, boiling water, liquid $\mathrm{N}_{2}$, and static air. Table 2 summarizes the 
measured TOF and $\theta_{\mathrm{Cu}-\mathrm{HCOO}}$ in 3 tests quenching the reaction in ice water, and Fig. 6 illustrates the relation between the measured formate surface coverage and the time it took to reach $383 \mathrm{~K}$ during quenching with the various cooling media (showing that ice water was most efficient). Table 2 shows that the TOF at $523 \mathrm{~K}$ is $(6.22 \pm 1.04) \cdot 10^{-3} \mathrm{~s}^{-1}$. Extrapolation of previously measured [40] rates for $\mathrm{R} 1$ on $\mathrm{Cu}$ to $523 \mathrm{~K}$ suggests that $\mathrm{R} 1$ should be 1-2 orders of magnitude faster than the TOF. Consequently, R1 should be quasi equilibrated under reaction conditions, and R2 is the rate limiting step in the reaction.

Table 2 Experimental parameters for each experiment with methanol synthesis over Raney $\mathrm{Cu}$ at $523 \mathrm{~K}, 50$ bar in $\mathrm{CO}_{2} / \mathrm{CO} / \mathrm{H}_{2}=3 / 29 / 68$ followed by quenching and TPD. Uncertainties correspond to two standard deviations, and the specific $\mathrm{Cu}$ surface area of Raney $\mathrm{Cu}$ was $5.2 \mathrm{~m}^{2} / \mathrm{g}_{\text {cat. }}$.

\begin{tabular}{|c|c|c|c|c|c|}
\hline & $\begin{array}{c}\text { Cooling } \\
\text { method }\end{array}$ & $\begin{array}{c}\text { Ave. time } \\
\text { to 383 K }[\mathbf{s}]\end{array}$ & $\begin{array}{c}\mathbf{m}_{\text {cat }} \\
{\left[\mathbf{m g}_{\text {cat }}\right]}\end{array}$ & $\begin{array}{c}\text { TOF } \\
{\left[\mathbf{C H}_{3} \mathbf{O H} \text { molecules }\right.} \\
\left(\mathbf{C u}_{\left.\text {surface atom })^{-\mathbf{1}} \mathbf{s}^{\mathbf{- 1}}\right]}\right.\end{array}$ & $\begin{array}{c}\boldsymbol{\theta}_{\mathbf{H C O O}} \\
{[\mathbf{M L}]}\end{array}$ \\
\hline Test 1 & Ice water & 1.1 & 258.43 & $5.63 \cdot 10^{-3}$ & 0.0640 \\
\hline Test 2 & Ice water & 0.5 & 254.36 & $6.46 \cdot 10^{-3}$ & 0.0748 \\
\hline Test 3 & Ice water & 1.4 & 259.54 & $6.59 \cdot 10^{-3}$ & 0.0730 \\
\hline Average & & 1 & & $(6.22 \pm 1.04) \cdot 10^{-3}$ & $0.071 \pm 0.012$ \\
\hline
\end{tabular}

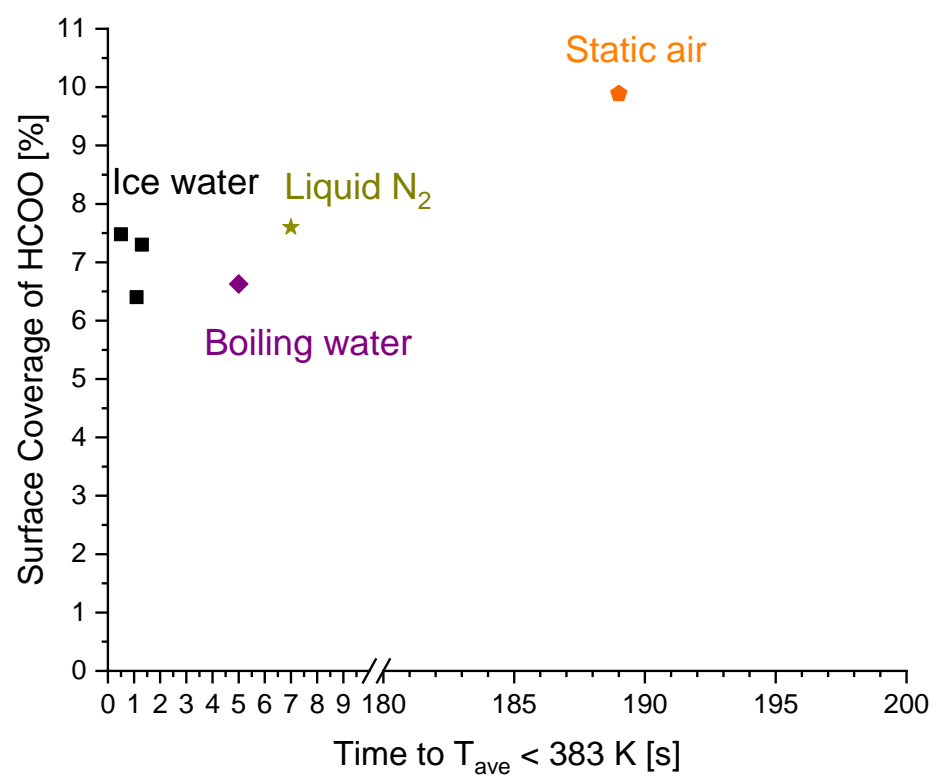

Fig. 6 Formate surface coverage as function of the time it takes the average temperature of the two thermocouples to reach $383 \mathrm{~K}$ using different cooling methods.

Adsorption reactions are by necessity exothermic to compensate for the loss of entropy, and this is also the case for R1 [40]. This means that during cooling the reverse reaction of R1 will stop 
before the forward reaction. Consequently, if the cooling is too slow, R1 will raise the HCOO coverage during cooling. Previous measurements [40] suggest that at $383 \mathrm{~K}$ the forward rate of R1 is 0.0013 formate molecules/Cu atom/second, which means that it would take several hundred seconds to cover the surface. This is so slow compared to the cooling that R1 can be regarded as terminated at $383 \mathrm{~K}$. Fig. 6 therefore evaluates the measured coverage as a function of time required to reach $383 \mathrm{~K}$ with various cooling methods. Fig. 6 shows that water based cooling methods yield a measured coverages that within uncertainty is independent of cooling rate, and this is taken as evidence that the cooling speed has reached the point, where the quenching is sufficiently fast to avoid that R1 modifies the coverage during cooling. Using liquid $\mathrm{N}_{2}$ as a cooling medium gives a slightly slower cooling. This is rationalized from a poor heat transfer in the gas film created when $\mathrm{N}_{2}$ boils around the hot reactor tube. However, the coverage obtained with the slower liquid $\mathrm{N}_{2}$ cooling seems, within the uncertainty, to be identical to the coverage obtained with ice water cooling. By contrast, cooling in static air is considerably slower, and Fig. 6 shows that this slower cooling does result in an increased coverage as expected from the exothermic nature of R1. Table 2 shows that quenching using ice water, which is concluded to be fast enough to avoid being influenced by R1 yields $\theta_{\mathrm{Cu}-\mathrm{HCOO}}=0.071 \pm 0.012 \mathrm{ML}$ (two standard deviations) and a corresponding TOF per adsorbed HCOO of $(6.22 \pm 1.04) \cdot 10^{-3} \mathrm{~s}^{-1} /(0.071 \pm 0.012 \mathrm{ML})=$ $0.088 \pm 0.021 \mathrm{~s}^{-1}$. This suggests that each surface formate species on average is converted to methanol every $1 /\left(0.088 \mathrm{~s}^{-1}\right) \cong 11.4$ seconds at $523 \mathrm{~K}$. This represents the time it would take R2 to remove all formate on the surface, if no new formate is generated. As quenching to below $383 \mathrm{~K}$ occurred rapidly compared to this lifetime, which increases exponentially with decreasing temperature, the reported formate coverage after ice water quenching was not significantly affected by R2. Since the quenching using ice water was concluded to be sufficiently fast to avoid major alterations of the coverage by both R1 and R2 during quenching the three ice water quenching tests (see Fig. 2, Fig. 6, and Fig. S1) were used to obtain the best estimate of the formate coverage on the working $\mathrm{Cu}$ surface, which as summarized in Table 2 is $\theta_{\mathrm{Cu}-\mathrm{HCOO}}=0.071 \mathrm{ML}$. Among existing micro-kinetic models the best agreement is with the model by Askgaard et al. [8] using $\mathrm{Cu}$ surface science data and the model by Grabow and Mavrikakis [9] using DFT calculations on $\mathrm{Cu}(111)$ both suggesting $\mathrm{HCOO}$ coverages of several percent at conditions similar to those used in the present study.

With the strong indications of a mechanism via formate [2-4], and assuming that all the detected formate on $\mathrm{Cu}$ participates in the reaction, the determined TOF per adsorbed HCOO of $0.088 \pm 0.021 \mathrm{~s}^{-1}$ should represent the best estimate of the true rate of the catalytic cycle for methanol synthesis on $\mathrm{Cu}$ at industrially relevant conditions.

\subsection{Oxygen coverage on $\mathrm{Cu}$ during methanol synthesis}

Previous studies [14, 33, 41, 42], which during methanol synthesis have flushed the reactor with inert gas before cooling and then quantified the free $\mathrm{Cu}$ surface with $\mathrm{N}_{2} \mathrm{O}-\mathrm{RFC}$, have observed the existence of oxygen species on the $\mathrm{Cu}$ surface of the working catalyst. However, the existence of adsorbed oxygen has caused debate [43-46], as it is surprising that any noteworthy oxygen buildup should occur in a reducing gas mixture at high pressure. Nevertheless, recent in situ ambient 
pressure XPS studies [47] also observed oxygen on the $\mathrm{Cu}$ surface during $\mathrm{CO}_{2}$ hydrogenation and thus call for further quantification of the oxygen coverage on $\mathrm{Cu}$ under industrially relevant methanol synthesis conditions. To verify that adsorbed oxygen is present on $\mathrm{Cu}$ during reaction conditions, unsupported $\mathrm{Cu}$ (from reduction of Sigma-Aldrich $\mathrm{CuO}$ nanopowder) was exposed to syngas $\left(\mathrm{CO}_{2} / \mathrm{CO} / \mathrm{H}_{2}=3 / 29 / 68\right)$ at 50 bar and $448 \mathrm{~K}$, quenched in syngas by ice water cooling and after He flush subjected to a TPH in a flow of $5 \mathrm{~mol} \% \mathrm{H}_{2}$ in $\mathrm{N}_{2}$. As shown in Fig. S13, water was evolved in the 293-393 K range during the TPH, which supports that there are oxygen species (O or $\mathrm{OH}$ ) on the $\mathrm{Cu}$ surface that can form water by reaction with $\mathrm{H}_{2}$. Quantification of the oxygen coverage on the working $\mathrm{Cu}$ surface was based on the evolution of $\mathrm{H} 2 \mathrm{O}$ during two TPH experiments on Raney $\mathrm{Cu}$ pre-covered by either (1) $0.5 \mathrm{ML}$ of oxygen after oxidation by $1 \mathrm{~mol} \%$ $\mathrm{N}_{2} \mathrm{O}$ at $333 \mathrm{~K}$ or (2) reaction intermediates after quenching during methanol synthesis. Figure 7 displays $\mathrm{H} 2 \mathrm{O}$ formation profiles after the $\mathrm{N} 2 \mathrm{O}$ oxidation (post $\mathrm{N}_{2} \mathrm{O}$ ) and the methanol synthesis and ice water quenching (post quenching). A minor water evolution was observed during TPH of the quenched sample, but such water evolution also occurred in TPH of a freshly reduced sample (see Fig. S13). The water evolution was therefore attributed to water impurities in the TPH feed that adsorb on the sample prior to the start of the TPH and then desorb in the initial stages of the $\mathrm{TPH}$ instead of being due to reduction of oxygen species on the $\mathrm{Cu}$ surface. Consequently, the oxygen coverage on the working $\mathrm{Cu}$ surface was concluded to be below the detection limit of our TPH method.

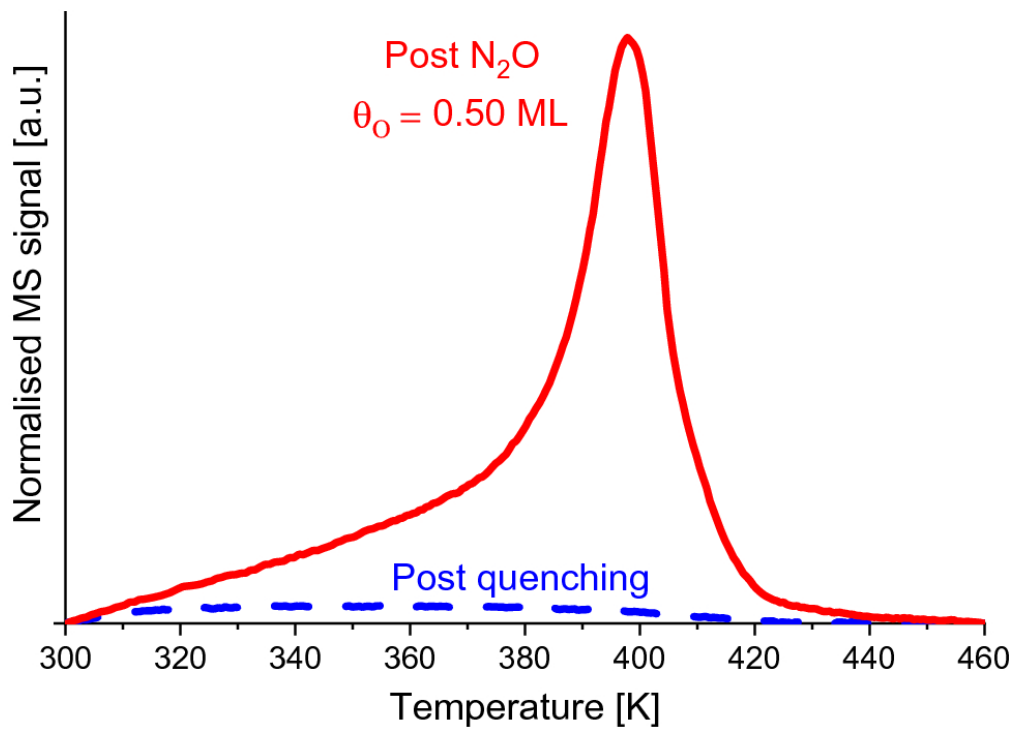

Fig. 7 The $\mathrm{H}_{2} \mathrm{O}$ signal in TPH as a function of temperature with Raney $\mathrm{Cu}$ after quenching during methanol synthesis at $523 \mathrm{~K}, 50$ bar of pressure in $\mathrm{CO}_{2} / \mathrm{CO} / \mathrm{H}_{2}=3 / 29 / 68$ (Post quenching) or after $\mathrm{N}_{2} \mathrm{O}-\mathrm{RFC}$ on pre-reduced Raney $\mathrm{Cu}\left(\right.$ Post $\mathrm{N}_{2} \mathrm{O}$ ). TPH conditions are $2 \mathrm{~K} / \mathrm{min}$ in $60 \mathrm{Nml} / \mathrm{min}$ of $5 \% \mathrm{H}_{2} / \mathrm{N}_{2}$. Both signals are individually and linearly baseline corrected using the specific data points at $\mathrm{T}=300 \mathrm{~K}$ and $\mathrm{T}=460 \mathrm{~K}$ for each experiment. 


\section{Conclusion}

A reproducible and quantitative method for estimating the surface coverage of adsorbate species under high temperature and high-pressure reactions conditions was outlined. Ice water provided the fastest cooling rate and fixated the surface coverages obtained at reaction conditions. Activity measurements in $\mathrm{CO}_{2} / \mathrm{CO} / \mathrm{H}_{2}$ at $523 \mathrm{~K}$ and 50 bar of pressure yielded a TOF per $\mathrm{Cu}$ surface atom of $(6.22 \pm 1.04) \cdot 10^{-3} \mathrm{~s}^{-1}$ for Raney $\mathrm{Cu}$ (all uncertainties are here two std. deviations). Based on the quenching method with ice water, the surface coverage of formate was determined to be $\theta_{\mathrm{Cu}-\mathrm{HCOO}}$ $=0.071 \pm 0.012 \mathrm{ML}$ for Raney $\mathrm{Cu}$ yielding a corresponding $\mathrm{TOF}$ per adsorbed $\mathrm{HCOO}$ of $0.088 \pm 0.021 \mathrm{~s}^{-1}$. Given the strong indications that the methanol synthesis proceeds via formate this TOF per adsorbed HCOO should represent the best estimate of the true rate of the catalytic cycle. Such estimations are vital for improving the understanding of kinetic reactions and guide kinetic modelling studies. Comparisons of Raney $\mathrm{Cu}$ to unsupported $\mathrm{Cu}$ and reports from single crystal studies suggested that Raney $\mathrm{Cu}$, at least in terms of methanol synthesis activity and $\mathrm{CO}_{2}$ hydrogenation properties, was a good approximation to pure $\mathrm{Cu}$. TPH of the Raney $\mathrm{Cu}$ surface post methanol synthesis suggested that the oxygen coverage on the working $\mathrm{Cu}$ surface was below the detection limit of our TPH method.

\section{Acknowledgements}

This work was supported by the Villum Foundation Center for Science of Sustainable Fuels and Chemicals, Villum Foundation V-SUSTAIN grant 9455.

\section{References}

1. Sehested J (2019) Industrial and scientific directions of methanol catalyst development. J Catal 371:368-375. https://doi.org/10.1016/j.jcat.2019.02.002

2. Fujita S, Usui M, Ito H, Takezawa N (1995) Mechanisms of Methanol Synthesis from Carbon Dioxide and from Carbon Monoxide at Atmospheric Pressure over $\mathrm{Cu} / \mathrm{ZnO}$. J Catal 157:403-413. https://doi.org/http://dx.doi.org/10.1006/jcat.1995.1306

3. Amenomiya Y (1984) Infrared study of methanol synthesis from CO2 + H2 on supported copper-sinc oxide catalysts. Proc 8th Int Congr Catal 557-567

4. Le Peltier F, Chaumette P, Saussey J, et al (1998) In situ FT-IR and kinetic study of methanol synthesis from $\mathrm{CO}_{2} / \mathrm{H}_{2}$ over $\mathrm{ZnAl}_{2} \mathrm{O}_{4}$ and $\mathrm{Cu}-\mathrm{ZnAl}_{2} \mathrm{O}_{4}$ catalysts. J Mol Catal A Chem 132:91-100. https://doi.org/10.1016/S1381-1169(97)00235-5

5. Lin S, Oldfield A, Klenerman D (2000) In-situ studies of polycrystalline copper during methanol synthesis at high pressure using sum frequency generation at surfaces. Surf Sci 464:1-7. https://doi.org/10.1016/S0039-6028(00)00706-8

6. Tarasov A, Seitz F, Schlögl R, Frei E (2019) In Situ Quantification of Reaction Adsorbates in Low-Temperature Methanol Synthesis on a High-Performance Cu/ZnO:Al Catalyst. ACS Catal 9:5537-5544. https://doi.org/10.1021/acscatal.9b01241 
7. Nakamura I, Fujitani T, Uchijima T, Nakamura J (1996) A model catalyst for methanol synthesis: Zn-deposited and Zn-free Cu surfaces. J Vac Sci Technol 14:1464-1468. https://doi.org/https://doi.org/10.1116/1.579970

8. Askgaard TS, Nørskov JK, Ovesen C V., Stoltze P (1995) A Kinetic Model of Methanol Synthesis. J Catal 156:229-242. https://doi.org/https://doi.org/10.1006/jcat.1995.1250

9. Grabow LC, Mavrikakis M (2011) Mechanism of Methanol Synthesis on Cu through $\mathrm{CO}_{2}$ and CO Hydrogenation. ACS Catal 1:365-384. https://doi.org/10.1021/cs200055d

10. Janse Van Rensburg W, Van Den Berg JA, Petersen MA, et al (2015) On the Kinetic Interpretation of DFT-Derived Energy Profiles: Cu-Catalyzed Methanol Synthesis. Catal Letters 145:559-568. https://doi.org/10.1007/s10562-014-1407-1

11. Studt F, Behrens M, Schlögl R, et al (2015) The Mechanism of CO and $\mathrm{CO}_{2}$ Hydrogenation to Methanol over Cu-Based Catalysts. ChemCatChem 7:1105-1111. https://doi.org/10.1002/cctc.201500123

12. Tameh MS, Dearden AK, Huang C (2018) Accuracy of Density Functional Theory for Predicting Kinetics of Methanol Synthesis from $\mathrm{CO}$ and $\mathrm{CO}_{2}$ Hydrogenation on Copper. $\mathbf{J}$ Phys Chem C 122:17942-17953. https://doi.org/10.1021/acs.jpcc.8b06498

13. Chorkendorff I, Taylor PA, Rasmussen PB (1992) Synthesis and hydrogenation of formate on $\mathrm{Cu}(100)$ at high pressures. J Vac Sci Technol A 10:2277-2281. https://doi.org/10.1116/1.577930

14. Chinchen GC, Waugh KC, Whan DA (1986) The activity and state of the copper surface in methanol synthesis catalysts. Appl Catal 25:101-107. https://doi.org/10.1016/S01669834(00)81226-9

15. Nielsen ND, Thrane J, Jensen AD, Christensen JM Bifunctional Synergy in CO Hydrogenation to Methanol with Supported $\mathrm{Cu}$. Catal Letters in press. https://doi.org/https://doi.org/10.1007/s10562-019-03036-7

16. Chinchen GC, Hay CM, Vandervell HD, Waugh KC (1987) The measurement of copper surface areas by reactive frontal chromatography. J Catal 103:79-86. https://doi.org/10.1016/0021-9517(87)90094-7

17. Chatterjee R, Kuld S, Berg R Van Den, et al (2019) Mapping Support Interactions in Copper Catalysts. Top Catal 62:649-659. https://doi.org/10.1007/s11244-019-01150-9

18. Hinrichsen $\mathrm{O}$, Genger T, Muhler M (2000) Chemisorption of $\mathrm{N}_{2} \mathrm{O}$ and $\mathrm{H}_{2}$ for the Surface Determination of Copper Catalysts. Chem Eng Technol 23:956-959. https://doi.org/10.1002/1521-4125(200011)23:11<956::AID-CEAT956>3.0.CO;2-L

19. Overbury SH, Bertrand PA, Somorjai GA (1975) The Surface Composition of Binary Systems. Prediction of Surface Phase Diagrams of Solid Solutions. Chem Rev 75:547560. https://doi.org/10.1021/cr60297a001

20. Laine J, Ceballos G, Severino F, et al (1991) Structure and activity of a Raney copper film catalyst. Catal Letters 10:11-17. https://doi.org/10.1007/BF00764731 
21. Li H, Belkind A, Jansen F, Orban Z (1997) An in situ XPS study of oxygen plasma cleaning of aluminum surfaces. Surf Coatings Technol 92:171-177.

https://doi.org/10.1016/S0257-8972(97)00079-0

22. Paparazzo E (1987) XPS and Auger Spectroscopy on mixtures of the oxides $\mathrm{SiO}_{2}, \mathrm{Al}_{2} \mathrm{O}_{3}$, $\mathrm{Fe}_{2} \mathrm{O}_{3}$, and $\mathrm{Cr}_{2} \mathrm{O}_{3}$. J Electron Spectros Relat Phenomena 43:97-112.

https://doi.org/https://doi.org/10.1016/0368-2048(87)80022-1

23. Rotole JA, Sherwood PMA (1998) Gamma-Alumina $\left(\gamma-\mathrm{Al}_{2} \mathrm{O}_{3}\right)$ by XPS. Surf Sci Spectra 5:18-24. https://doi.org/10.1116/1.1247852

24. Pan WX, Cao R, Roberts DL, Griffin GL (1988) Methanol synthesis activity of CuZnO catalysts. J Catal 114:440-446. https://doi.org/http://dx.doi.org/10.1016/00219517(88)90047-4

25. Argyle M, Bartholomew C (2015) Heterogeneous Catalyst Deactivation and Regeneration: A Review. Catalysts 5:145-269. https://doi.org/10.3390/catal5010145

26. Chinchen GC, Mansfield K, Spencer MS (1990) The methanol synthesis: How does it work. Chemtech 20:692-699

27. Nakamura I, Fujitani T, Uchijima T, Nakamura J (1996) A model catalyst for methanol synthesis: Zn-deposited and Zn-free Cu surfaces. J Vac Sci Technol A 14:1464-1468. https://doi.org/10.1063/1.451126

28. Yoshihara J, Parker SC, Schafer A, Campbell CT (1995) Methanol synthesis and reverse water-gas shift kinetics over clean polycrystalline copper. Catal Letters 31:313-324. https://doi.org/10.1007/BF00808595

29. Redhead PA (1961) Chemisorption on polycrystalline tungsten. Trans Faraday Soc 57:641-656. https://doi.org/10.1039/TF9615700641

30. Niemantsverdriet JW, Chorkendorff I (2003) Concepts of Modern Catalysis and Kinetics. Wiley-VCH

31. Iglesia E, Boudart M (1983) Decomposition of formic acid on copper, nickel, and coppernickel alloys. I. Preparation and characterization of catalysts. J Catal 81:204-213. https://doi.org/10.1016/0021-9517(83)90158-6

32. Bowker M (1983) Chemisorption and industrial catalytic processes. Vacuum 33:669-685. https://doi.org/10.1016/0042-207X(83)90591-2

33. Bowker M, Hadden RA, Houghton H, et al (1988) The mechanism of methanol synthesis on copper/zinc oxide/alumina catalysts. J Catal 109:263-273.

https://doi.org/10.1016/0021-9517(88)90209-6

34. Yao Y, Zaera F (2016) Adsorption and thermal chemistry of formic acid on clean and oxygen-predosed $\mathrm{Cu}(110)$ single-crystal surfaces revisited. Surf Sci 646:37-44. https://doi.org/10.1016/j.susc.2015.06.007

35. Tamm S, Ingelsten HH, Skoglundh M, Palmqvist AEC (2010) Mechanistic aspects of the selective catalytic reduction of NOx by dimethyl ether and methanol over $\gamma-\mathrm{Al}_{2} \mathrm{O}_{3}$. J Catal 
276:402-411. https://doi.org/10.1016/j.jcat.2010.10.004

36. Amenomiya Y (1979) Active Sites of Solid Acidic Catalysts III Infrared Study of the Water Gas Conversion Reaction on Alumina. 57:64-71. https://doi.org/https://doi.org/10.1016/0021-9517(79)90043-5

37. Ovesen C V., Clausen BS, Hammershøi BS, et al (1996) A microkinetic analysis of the water-gas shift reaction under industrial conditions. J Catal 158:170-180. https://doi.org/10.1006/jcat.1996.0016

38. Zhang Z, Wang SS, Song R, et al (2017) The most active $\mathrm{Cu}$ facet for low-Temperature water gas shift reaction. Nat Commun 8:488. https://doi.org/10.1038/s41467-017-00620-6

39. Berteau P, Ceckiewicz S, Delmon B (1987) Role of the acid-base properties of aluminas, modified $\gamma$-alumina, and silica-alumina in 1-butanol dehydration. Appl Catal 31:361-383. https://doi.org/https://doi.org/10.1016/S0166-9834(00)80702-2

40. Taylor PA, Rasmussen PB, Ovesen C V., et al (1992) Formate synthesis on Cu(100). Surf Sci 261:191-206. https://doi.org/https://doi.org/10.1016/0039-6028(92)90231-T

41. Chinchen GC, Waugh KC (1986) The chemical state of copper during methanol synthesis. J Catal 97:280-283. https://doi.org/10.1016/0021-9517(86)90063-1

42. Chinchen GC, Spencer MS, Waugh KC, Whan DA (1987) Promotion of methanol synthesis and the water-gas shift reactions by adsorbed oxygen on supported copper catalysts. J Chem Soc Faraday Trans 1 83:2193-2212. https://doi.org/10.1039/f19878302193

43. Campbell CT (1987) Comments on: The activity and state of the copper surface in methanol synthesis. Appl Catal 32:367-369. https://doi.org/https://doi.org/10.1016/S01669834(00)80641-7

44. Chinchen GC, Spencer MS, Waugh KC, Whan DA (1987) Reply to "comments on the activity and state of the copper surface in methanol synthesis catalysts [1]." Appl Catal 32:371-372. https://doi.org/https://doi.org/10.1016/S0166-9834(00)80642-9

45. Nakamura J, Rodriguez JA, Campbell CT (1989) Does $\mathrm{CO}_{2}$ dissociatively adsorb on $\mathrm{Cu}$ surfaces? J Phys Condens Matter 1:149-160. https://doi.org/10.1088/0953-8984/1/SB/026

46. Muhler M, Törnqvist E, Nielsen LP, et al (1994) On the role of adsorbed atomic oxygen and $\mathrm{CO}_{2}$ in copper based methanol synthesis catalysts. Catal Letters 25:1-10. https://doi.org/10.1007/BF00815409

47. Ren Y, Yuan K, Zhou X, et al (2018) Catalytic Intermediates of $\mathrm{CO}_{2}$ Hydrogenation on $\mathrm{Cu}(111)$ Probed by In Operando Near-Ambient Pressure Technique. Chem - A Eur J 24:16097-16103. https://doi.org/10.1002/chem.201802931 